\title{
On the minimal thermal habitability conditions in low income dwellings in Spain for a new definition of fuel poverty
}

\section{ABSTRACT}

Fuel poverty can be defined as "the inability to afford adequate warmth in the home". The concept was firstly developed due to health risks related to cold among low income households. However, in the last few decades, especially since the summer heat wave of 2003 that caused 35,000 deaths across Europe, a lot of research has been conducted about the health risks related to high temperatures.

Along with advances in knowledge related to the health risks associated with inadequate temperatures, several directives of the European Commission related to energy regulation urge Member States to develop their own fuel poverty definitions. This need of a methodological development for new definitions poses several questions. First, what should be the temperature thresholds for the overheated season? But, furthermore, are existing temperature baselines adequate for the Spanish context and climate?

This paper presents a preliminary approach to define these new temperature thresholds for the Spanish context through the adaptive comfort model criteria. For that purpose, a statistically representative dwelling building typology of vulnerable household spaces was used to analyze indoor thermal temperatures and hence, to establish minimal energy requirements so as to achieve minimal habitability conditions.

\section{Keywords}

adaptive comfort, fuel poverty, housing stock, Spain, low income, energy consumption

\section{Introduction}

\subsection{Relevance of research}

Fuel poverty is an increasing matter of interest within the EU, as expressed in recent directives $[1,2]$ where the European Commission urges Member States to define their vulnerable citizens as well as to invest in order to tackle fuel poverty [3,4]. In line with these directives, Europe 2020 Strategy takes into account those households unable to afford adequate warmth at home [5]. 
One of the most severe consequences of fuel poverty is health risks associated with being regularly exposed to excess cold or heat. This has led researchers, governments and activists to focus on fuel poverty. One of the first attempts to define fuel poverty in the UK was presented in the Warm Homes and Energy Conservation Act, which defined fuel poverty as follows:

'a person is to be regarded as living 'in fuel poverty' if he is a member of a household living on a lower income in a home which cannot be kept warm at a reasonable cost' [6].

Similarly, the EU statistics on income and living conditions consider 'the ability to keep the home adequately warm'. It must be highlighted that the focus has traditionally been on cold associated diseases while health risks related to high temperatures at home have been less researched until recently.

Many other European countries, such as Ireland [7,8] and France [9] [10], have already established fuel poverty definitions, or have taken first steps to establish a definition of fuel poverty, such as in Romania [11]. Nonetheless, the problem is yet to be defined in most Member States. Developing new definitions of fuel poverty across the EU is challenging, primarily due to the difficulty in extrapolating existing national definitions to other countries arising from differences in climate, income levels, housing stocks and heating and cooling systems across Member States.

On the one hand, as a response to these variations across countries and given the increasing interest of researchers in defining the problem, new approaches to fuel poverty have been developed. These studies have focused on particular driving forces of the problem; the energy market deregulation in Eastern post-communist countries [12], the energy transition in Germany [13], the economic recession in Greece [14], household socioeconomic factors in France [15], or building energy performance [16] and type of available energy in Italy [17]. Also, recent definitions of fuel poverty, such as 'the inability to attain a socially and materially necessitated level of domestic energy services' [18] aim to adopt a more holistic approach towards the investigation of the problem by dissolving the traditional dichotomy between energy conservation strategies and strategies aiming to tackle fuel poverty. 
On the other hand, indoor overheating problems have been identified in studies related to low income households carried out in warmer European countries, such as Portugal [19] and Greece [20], as well as heating dominated countries, such as the UK [21,22].

Taking the above into consideration, new definitions of fuel poverty for Southern European countries should be considered by factoring in regional variations in climate, built environment and socioeconomic characteristics. Climate is a key factor, and hence, new methods should revise temperature baselines for the cold season as well as consider health risks related to high temperatures and delimitate the acceptable thermal conditions for the summer season.

\subsection{Aims and objectives of the study}

This paper aims to identify the minimal thermal habitability conditions that need to be achieved in low income dwellings in Spain in order to lay the foundations for a new definition methodology of fuel poverty in this country. To this end, the following objectives are set:

- To establish minimal thermal habitability conditions for dwellings

- To evaluate the minimal energy needs related to these thermal habitability conditions

- To compare these minimal energy needs to Spanish regulatory energy demand calculations

\section{Fuel poverty and health}

Research on the energy performance of low income family dwellings has been undertaken in Germany [23], Greece [24,25], Cyprus [26], Spain [27,28] and Europe as a whole [29]. Households suffering from fuel poverty often have to reduce the use of heating and cooling facilities and, as a result, live under inadequate thermal conditions that may expose them to severe health risks.

\subsection{Health risks associated with living under inadequate temperatures}

The health risks related to living in cold homes have been widely investigated since the first fuel poverty studies were developed in cold weather countries. Excess winter mortality and its association with the lack of building thermal insulation has been widely studied [30,31] 
In 1982, a World Health Organization working group carried out a review of evidence regarding connections between indoor temperatures and health and established that health risks were lower for temperatures between $18^{\circ} \mathrm{C}$ and $24^{\circ} \mathrm{C}$ [32]. However, this study has been widely criticised because it was not based on specific studies [33]. A later study referred to these temperatures but also established that it was not possible to set the mean temperature below which the population can be considered at risk [34]. A more recent report from the Marmot Review Team presented a summary of existing knowledge regarding cold temperature health impacts [35]. Its main conclusions were as follows: (a) countries with better building thermal insulation levels are characterised by lower excess winter mortality, (b) there is evidence of the relation between excess winter mortality and dwelling low indoor temperature, (c) mental health is also negatively affected by low indoor temperatures.

The importance of health risks related to high temperatures has been increasingly recognised in recent years. The research interest on the adverse impacts of building overheating has been partly triggered by the heat wave of 2003 that caused up to 45,000 deaths in 12 European countries [36]. Before 2003, several studies, some of which conducted for the city of Madrid [38], had already pointed out the relationship between high temperatures and mortality [37]. Similarly to cold temperature impacts, children and older people as well as people suffering from diseases such as diabetes or neurological disorders were found to be more vulnerable to high temperatures. In 1995, the heat wave that took place in Chicago resulted in higher negative impacts amongst the lower socioeconomic level population segments, probably related to worse thermal habitability conditions in dwellings occupied by these parts of the population [39].

Climate change scenarios [40] predict an increase in the frequency and intensity of heat waves, which is likely to lead to a rise in in excess summer mortality. Public health authorities activate mechanisms for the protection of the population based on the temperature that corresponds to the $95^{\text {th }}$ percentile of daily maximum temperature series of summer months. This temperature varies depending on the climate of each location, which indicates the adaptation of the population to the climate they live in [41]. In line with this adaptation phenomenon, existing studies have found that the relationship between mortality rates and ambient temperature follows a $\mathrm{V}$ or a $\mathrm{J}$ shape (Baccini, 2008); mortality rises when the environmental temperature decreases or increases from a fixed comfort temperature zone within which minimum mortality occurs. Therefore, the minimum 
mortality temperature is higher in Mediterranean cities while in northern cities this temperature is lower as shown in Figure 1. These studies reinforce the idea that populations adapt to the climate they live in. Minimal mortality temperature decreases when latitude increases and vice versa [42].
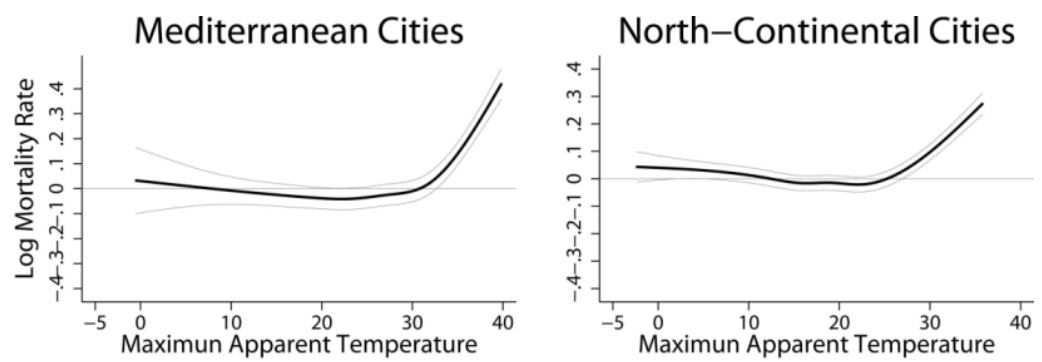

Figure 1. Regression graphs that show the relationship between Maximum Apparent Temperature and the Logarithm of Mortality Rate in Mediterranean and Northern cities. Source: Baccini (2008).

\subsection{Health and thermal comfort}

Existing evidence of the close relationship between temperature and health is directly linked to the study of thermal comfort. Some of the first studies relating health and thermal comfort analysed the human body capacity to adapt to a small range of temperatures from $15^{\circ} \mathrm{C}$ to $25^{\circ} \mathrm{C}$. Body energy waste is minimum within that interval, which was defined as the indifferent metabolism zone' [43].

More recent reports from WHO have suggested that achieving thermal comfort is not only a matter of providing thermal satisfaction but also promoting health [33]. Along these lines, project LARES (Large Analysis and Review of European housing and health Status) (WHO Europe, 2007), conducted a review of thermal comfort and energy efficiency studies in ten EU countries with the aim to establish guidelines to protect population health. It also intended to alert governments to the existing evidence of how thermal discomfort in dwellings directly affects health. Results from this project showed a relationship between health problems and lack of thermal comfort, dwelling low energy performance and dampness problems. Based on the LARES results, WHO recognising the need for specific indoor temperature thresholds for domestic environments to ensure the protection of human health and wellbeing.. 


\section{Thermal comfort}

Approaches to thermal comfort can be divided into two groups; the static approach based on Fanger's studies [45] and the dynamic approach, first enunciated by Humphreys [46]. Fanger's studies are based on the heat exchange between the human body and the ambient environment and have been widely used, through the ISO 7730, for evaluating thermal comfort in spaces with mechanically controlled environments such as offices [47]. By contrast, the dynamic approach approaches thermal comfort from another perspective. Occupants are not seen as passive subjects but active individuals that will make all possible adjustments in order to achieve thermal comfort [48].

Studies of adaptive thermal comfort were developed in real-world environments, mainly in free running buildings where occupants were able to adapt to their thermal environment through adjustments to their clothing, activity levels etc. In these buildings, occupant comfort temperature was found to be closely related to external monthly mean temperatures as presented in Figure 2. Furthermore, comfort temperatures indicated by occupants covered a wider range of temperatures than those predicted by Fanger's model, especially in summer [49,50].

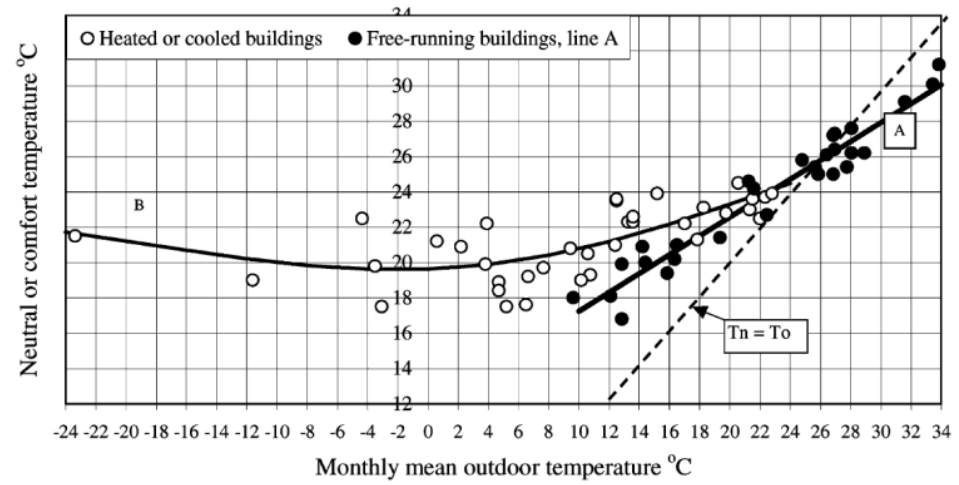

Figure 2. Changes in comfort temperatures with external monthly mean temperatures. Each point represents the mean value of every survey. Source: Humphreys [46].

The three fundamental categories of adaptation according to the adaptive thermal comfort theory are (Folk 1974, 1981, Goldsmith 1974, Prosser 1958, Clark and Edholm 1985, Brager \& De Dear, 1998):

a) Behavioural adjustments, such as changing clothing insulation levels, changing activity levels, taking cold or hot drinks or changing position within a room. 
b) Environmental adjustments, such as opening windows, using solar shading, varying heating thermostat settings.

c) Physiological adjustments, such as the body's response to exposure to some environmental factors that will gradually reduce the effort caused by that exposure [52,53]. This adaptation can be divided in two types: the acclimatization that takes place within a period of days, and genetic adaptation in which the adaptation is incorporated in the genetic inheritance.

d) Psychological adjustments related to the individual's expectations [54,55].

\subsection{Adaptive thermal standards: the EN15251 and the ASHRAE 55-2010}

Two main standards have been derived from this approach, the European Standard, the EN15251 developed from 'Smart Controls and Thermal Comfort - the Smart Controls and Thermal Comfort (SCAT) project conducted by McCartney and Nicols and the ANSI-ASHRAE 55:2004 adaptive standard based on Brager and de Dear's research in the RP-884 Project.

In the EN15251:2006 Standard [56], comfort temperature is based on the temperatures of previous days as shown in following formula:

$\theta_{c}=0.33 \theta_{r m}+18.8^{\circ} \mathrm{C}$

Where $\theta_{c}$ is the comfort operative temperature (in ${ }^{\circ} \mathrm{C}$ ) and $\theta_{r m}$ is the exponentially weighted running mean of the daily mean external air temperature (in ${ }^{\circ} \mathrm{C}$ ) that can be calculated in a simplified way as follows:

$$
\theta_{r m}=\left(\theta_{e d-1}+0.8 \theta_{e d-2}+0.6 \theta_{e d-3}+0.5 \theta_{e d-4}+0.4 \theta_{e d-5}+0.3 \theta_{e d-6}+0.2 \theta_{e d-7}\right) / 3.8
$$

Where $\theta_{e d-1}$ is the daily mean external temperature for the previous day (in ${ }^{\circ} \mathrm{C}$ ), $\theta_{e d-2}$ is the daily mean external temperature for the day before (in ${ }^{\circ} \mathrm{C}$ ) and so on. From the calculated comfort temperature, comfort thresholds are estimated for three environmental categories (I, II, III), depending on occupant requirements. Figure 3 shows the boundaries of operative comfort temperature related to the outdoor running mean temperature. 


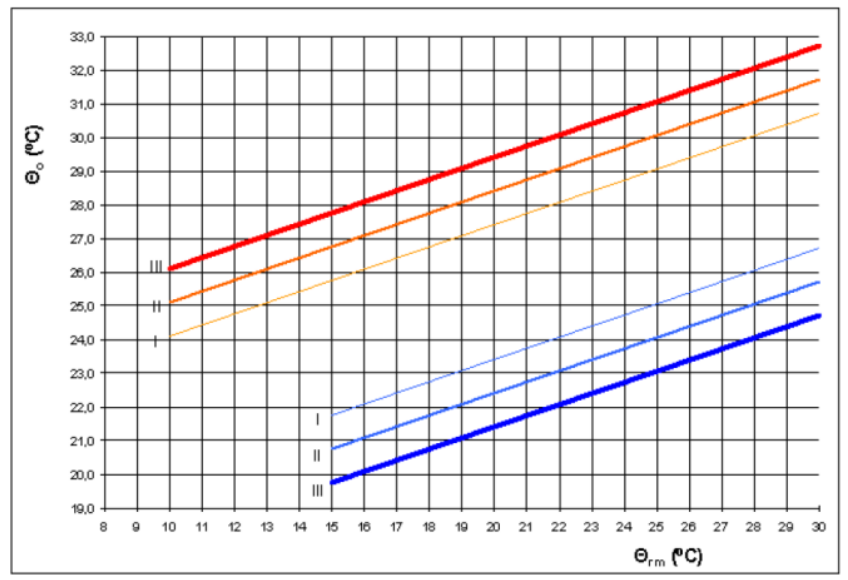

$\theta_{\text {rm }}=$ Outdoor Running mean temperature ${ }^{\circ} \mathrm{C} ; \theta_{\mathrm{o}}=$ Operative temperature ${ }^{\circ} \mathrm{C}$

Figure 3 Design values for the indoor operative temperature for buildings without mechanical cooling systems as a function of the exponentially-weighted running mean of the outdoor temperature.

The ASHRAE 55-2010 Standard [57] also determines indoor comfort temperature according to external temperature as shown in the formula below:

$T_{o t}=0.31 T_{o}+17.8^{\circ} \mathrm{C}$

Where $T_{o t}$ is indoor comfort operative temperature (in ${ }^{\circ} \mathrm{C}$ ) and $T_{o}$ is the mean outdoor temperature of previous days (in ${ }^{\circ} \mathrm{C}$ ). Using the calculated comfort temperature, comfort boundaries are determined for the $80 \%$ and $90 \%$ of satisfied occupants, as plotted in Figure 4.

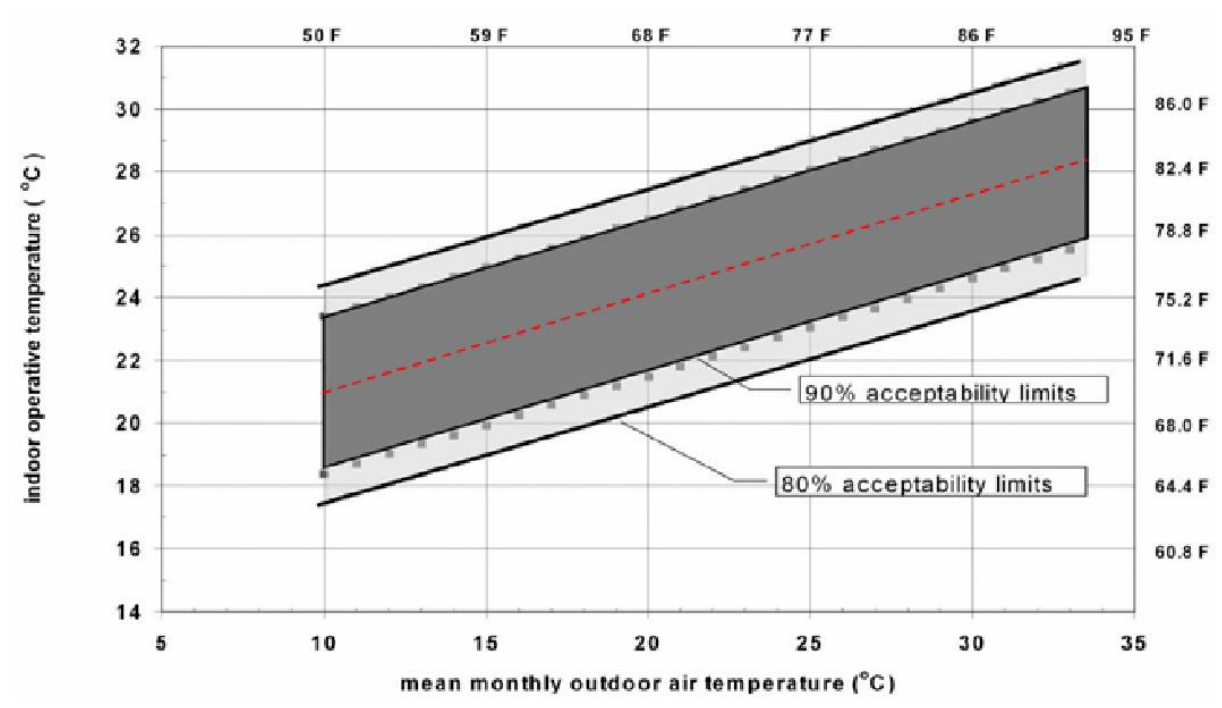

Figure 4 Acceptable operative temperature ranges for naturally conditioned spaces. 
The main differences between the two standards are [58]:

- Geographical scope: The ASHRAE 55-2004 database covers Australia, Southeast Asia, India, Mediterranean countries, East Europe and North America. On the contrary, the EN15251 standard is based on data collected during the European project SCATS.

- Building type: In the ASHRAE standard, 9,000 out of the 21,000 questionnaires (36 buildings out of 160) were carried out in naturally ventilated buildings, mainly offices and industrial but also residential buildings. In the SCATS project, 1,449 out of 4,655 of questionnaires were also conducted in naturally ventilated buildings but the focus was only on office buildings.

- Estimation of the neutral temperature (the optimal temperature at which occupants express thermal neutrality): The ASHRAE database was wide enough to establish statistically significant regressive models. On the contrary, EN15251 model applied Griffiths' model including several limitations [59].

- Estimation of the running mean outdoor temperature: While ASHRAE enables the use of the mean monthly temperature, EN15251 uses a weighted mean temperature of the last 15 days. ASHRAE's temperature calculation is under revision, but the utilization of the mean monthly temperature makes the calculation of this value easier in regions where temperatures of previous days are not available.

It should be highlighted that despite the fact that these adaptive standards do not specifically consider mixed mode buildings where natural ventilation is combined with heating and cooling systems, there are studies that demonstrate that occupant thermal comfort in these buildings is closer to the predictions of the adaptive model rather than those of Fanger's model.

Studies analyzing building data from the ASHRAE RP-884 project have showed a statistically representative correlation between occupants' control perception over their own environment and their comfort experience in actively conditioned spaces (Langevin, Wen y Gurian, 2012). Similar results were obtained in Japanese offices where occupants had more opportunities of making adjustments than generally expected in centralized air conditioning buildings (Goto et al., 2007). A seminal study by Leaman and Bordass concluded that occupants' comfort, health and productivity is closely related to their perception of controlling thermal comfort parameters (Leaman and Bordass, 1999). Adaptive standards are being applied to offices with a mixed mode air conditioning system in order to achieve energy savings (Dear, 2007; Pfafferott et al., 2007; Wagner et al., 2007). 


\subsection{Thermal comfort studies in dwellings}

The thermal standards described previously were developed so as to evaluate thermal comfort mainly in office spaces. However, the ASHRAE RP-884 project covered some residential buildings wherein some particularities were detected:

a) The mean operative temperature was $6^{\circ} \mathrm{C}$ higher in residential buildings compared to offices in summer and $3.8^{\circ} \mathrm{C}$ lower in winter.

b) Air velocity rates were higher; $0.07 \mathrm{~m} / \mathrm{s}$ more in winter and $0.18 \mathrm{~m} / \mathrm{s}$ higher in summer.

c) Clothing levels also differed. Variations among seasons were much higher in dwellings. Clothing levels ranged between 1.18 and 1.5 clo in winter, and between 0.42 and 0.74 clo in summer.

These findings were in line with Oseland's [60] experimental results that showed that thermal comfort thresholds are more flexible in domestic spaces compared to offices. Other studies conducted in domestic spaces, such as the ones carried out in dwellings in Israel [61] and Belgium [62] also found occupants' thermal comfort responses to be closer to the adaptive behaviour model rather than Fanger's model. In summary, thermal comfort studies have shown that occupants' adaptation capabilities are higher in dwellings compared to office spaces, which results in thermal comfort levels in residential spaces to be closer to the adaptive behavior model.

\section{Materials and methods}

\subsection{Geographic scope}

This study aims to establish minimal thermal habitability conditions for low income dwellings in Spain so it was considered important to work with climatic regions that could represent the whole range of climatic conditions that can be found within the country. In Spain, climatic regions are defined by the Building technical Code (Código Técnico de la Edificación - CTE by its initials in Spanish), which classifies weather conditions according to winter severity, with ranges from A for those regions with mild winters to $\mathrm{E}$ for the most severe conditions, and summer severity, that goes from 1 for the coldest regions and 4 for the warmest summers [63]. 


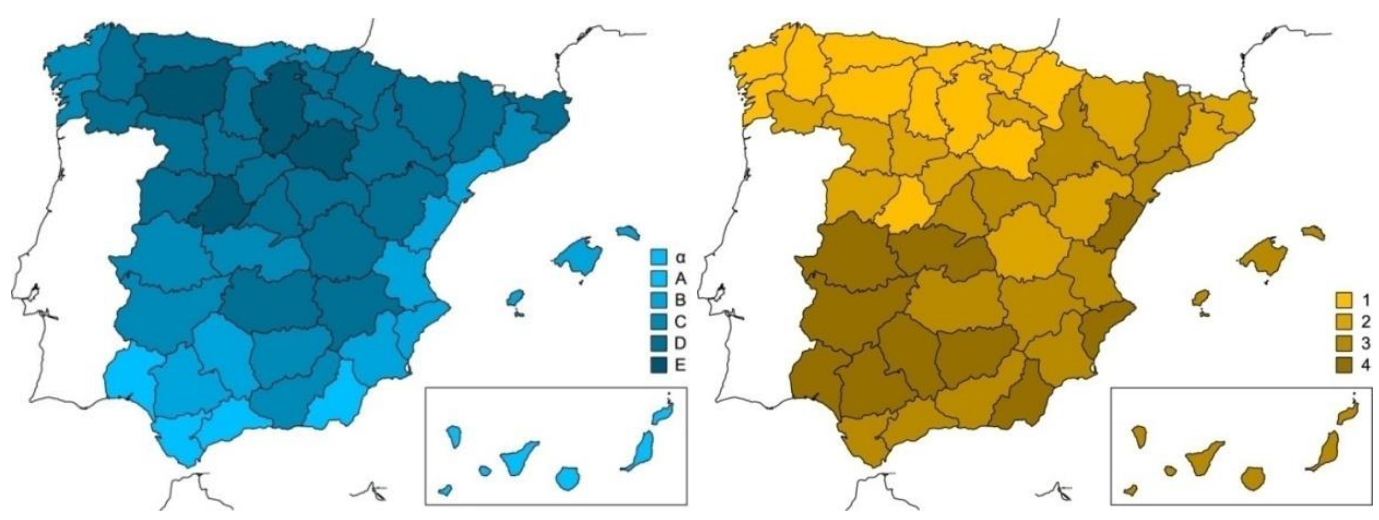

Figure 5 Spanish winter severity (left) and summer severity (right) by provinces [64].

Three capital provinces broadly representative of the Spanish climate were chosen; Ávila was selected for its highest winter severity (E1); Seville was selected for having the highest summer severity (B4) and Madrid, with an intermediate weather (D3). Table 1 presents a summary of main weather data for each of the selected cities.

Table 1. Weather data of selected cities [65]

\begin{tabular}{|c|c|c|c|c|c|c|c|c|c|c|c|c|c|}
\hline & & Jan & Feb & Mar & Apr & May & Jun & Jul & Aug & Sep & Oct & Nov & Dec \\
\hline \multirow{4}{*}{ Ávila } & Mean temp. $\left({ }^{\circ} \mathrm{C}\right)$ & 3 & 4.3 & 6.7 & 8.5 & 12.5 & 17.4 & 20.6 & 20.2 & 16.5 & 11.4 & 6.4 & 4 \\
\hline & Maximum (mean) temp. $\left({ }^{\circ} \mathrm{C}\right)$ & 7.6 & 9.4 & 12.6 & 14.3 & 18.5 & 24.6 & 28.5 & 27.9 & 23.4 & 16.9 & 11.2 & 8.4 \\
\hline & Minimum (mean) temp. $\left({ }^{\circ} \mathrm{C}\right)$ & -1.6 & -0.8 & 0.8 & 2.7 & 6.4 & 10.2 & 12.6 & 12.4 & 9.6 & 5.9 & 1.7 & -0.4 \\
\hline & Relative humidity (\%) & 78 & 72 & 63 & 63 & 59 & 51 & 43 & 45 & 56 & 69 & 78 & 79 \\
\hline \multirow{4}{*}{ Madrid } & Mean temp. $\left({ }^{\circ} \mathrm{C}\right)$ & 6.3 & 7.9 & 11.2 & 12.9 & 16.7 & 22.2 & 25.6 & 25.1 & 20.9 & 15.1 & 9.9 & 6.9 \\
\hline & Maximum (mean) temp. $\left({ }^{\circ} \mathrm{C}\right)$ & 9.8 & 12 & 16.3 & 18.2 & 22.2 & 28.2 & 32.1 & 31.3 & 26.4 & 19.4 & 13.5 & 10 \\
\hline & Minimum (mean) temp. $\left({ }^{\circ} \mathrm{C}\right)$ & 2.7 & 3.7 & 6.2 & 7.7 & 11.3 & 16.1 & 19 & 18.8 & 15.4 & 10.7 & 6.3 & 3.6 \\
\hline & Relative humidity (\%) & 71 & 65 & 55 & 56 & 53 & 44 & 38 & 41 & 50 & 64 & 71 & 74 \\
\hline \multirow{4}{*}{ Seville } & Mean temp. $\left({ }^{\circ} \mathrm{C}\right)$ & 10.9 & 12.5 & 15.6 & 17.3 & 20.7 & 25.1 & 28.2 & 27.9 & 25 & 20.2 & 15.1 & 11.9 \\
\hline & Maximum (mean) temp. $\left({ }^{\circ} \mathrm{C}\right)$ & 16 & 18.1 & 21.9 & 23.4 & 27.2 & 32.2 & 36 & 35.5 & 31.7 & 26 & 20.2 & 16.6 \\
\hline & Minimum (mean) temp. $\left({ }^{\circ} \mathrm{C}\right)$ & 5.7 & 7 & 9.2 & 11.1 & 14.2 & 18 & 20.3 & 20.4 & 18.2 & 14.4 & 10 & 7.3 \\
\hline & Relative humidity (\%) & 71 & 67 & 59 & 57 & 53 & 48 & 44 & 48 & 54 & 62 & 70 & 74 \\
\hline
\end{tabular}

\subsection{Representative archetypes of vulnerable households}

Representative archetypes of vulnerable households were selected for the evaluation of indoor thermal conditions. In Spain, there is no georeferenced income data available in order to detect the most disadvantaged neighbourhoods. This shortfall led, in 1996, to the OECD developing a study of deprived neighbourhoods. In Spain, it was conducted in cooperation with the Ministry of Public Works and resulted into the Spanish Vulnerable Neighbourhood Catalogue [66] where urban areas 
beyond certain levels of socioeconomic and material deprivation rates were identified. The last report showed the highest rates of vulnerable population living in urban developments built between 1960 and 1975, before the introduction of the first Spanish Thermal Regulation [67] and represent $17.63 \%$ of all vulnerable neighbourhoods.

These urban areas built during this period in the three selected cities were analysed and three of them were selected due to the presence of the most representative archetype in those years: the linear block as presented in Table 2.

The three blocks selected consist of four to five storeys where each staircase connects two dwellings in each floor. Dwelling floor areas range from 45 to $60 \mathrm{~m}^{2}$. Thermal construction properties are shown in Table 3.

Table 2. Selected linear building blocks
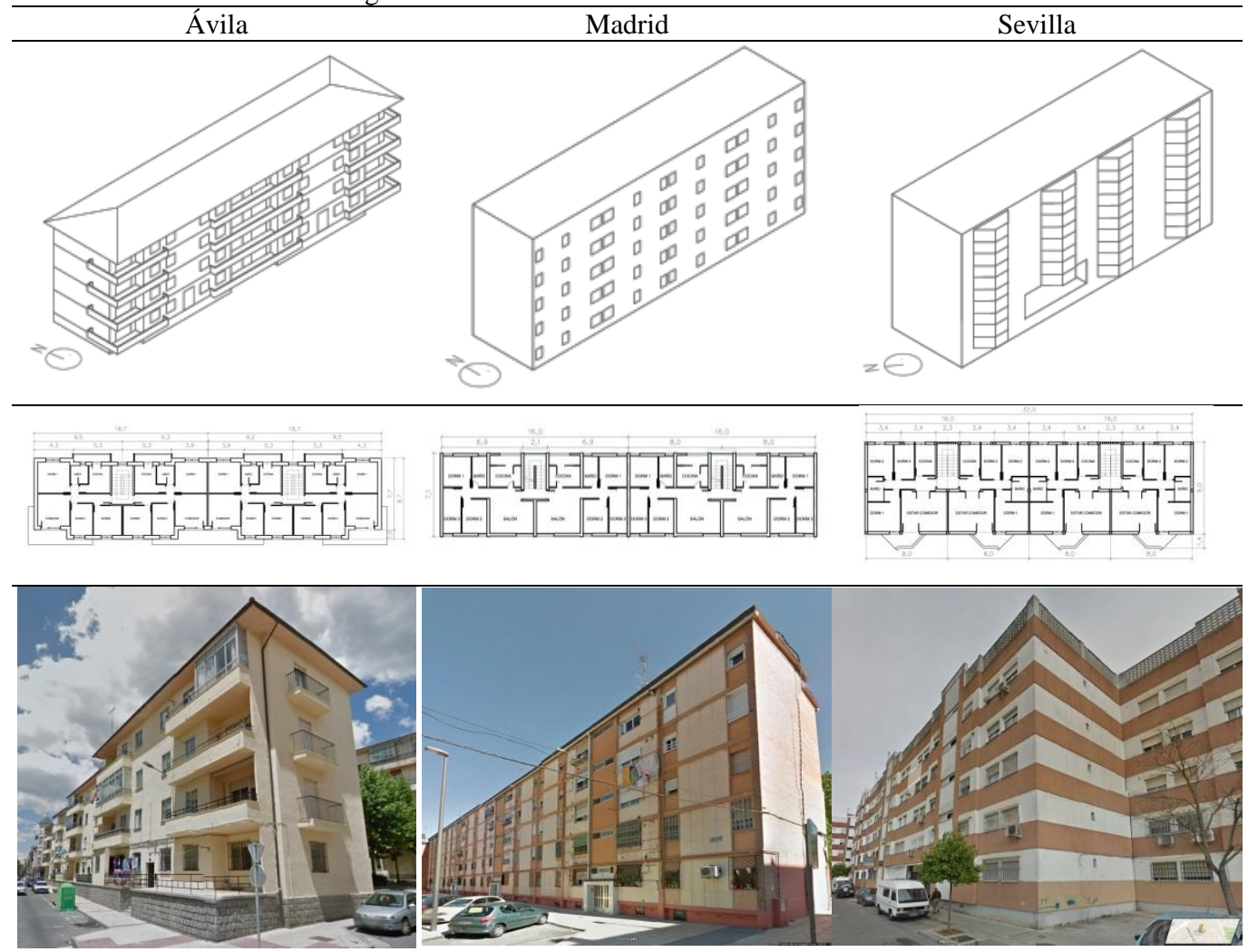
Table 3.. Thermal construction properties of studied blocks

\begin{tabular}{lcccccc}
\hline & \multicolumn{2}{c}{ Ávila } & \multicolumn{2}{c}{ Madrid } & \multicolumn{3}{c}{ Seville } \\
& {$\left[\mathrm{W} / \mathrm{m}^{2} \mathrm{~K}\right]$} & {$\left[\mathrm{kJ} / \mathrm{m}^{2} \mathrm{~K}\right]$} & {$\left[\mathrm{W} / \mathrm{m}^{2} \mathrm{~K}\right]$} & {$\left[\mathrm{kJ} / \mathrm{m}^{2} \mathrm{~K}\right]$} & {$\left[\mathrm{W} / \mathrm{m}^{2} \mathrm{~K}\right]$} & {$\left[\mathrm{kJ} / \mathrm{m}^{2} \mathrm{~K}\right]$} \\
\hline Walls & 1.33 & 114.15 & 2.38 & 199.15 & 1.7 & 57.25 \\
\hline Flat roof & - & - & 2.18 & 142.72 & 2.18 & 142.72 \\
\hline Pitched roof & 1.96 & 81.5 & - & - & - & - \\
\hline $\begin{array}{l}\text { Floor under } \\
\text { pitched roof }\end{array}$ & 2.37 & 136.9 & - & - & - & - \\
\hline Floor & 2.37 & 137.65 & 2.12 & 144.63 & 2.37 & 137.65 \\
\hline Ground floor & 2 & 189.45 & - & - & - & - \\
\hline $\begin{array}{l}\text { Ground floor with } \\
\text { air chamber }\end{array}$ & - & - & 2.82 & 144.62 & 2.82 & 144.62 \\
\hline $\begin{array}{l}\text { Windows } \\
\text { glazing/frame })\end{array}$ & $5.78 / 5.26$ & & $5.78 / 5.26$ & & $5.78 / 5.26$ & \\
\hline \begin{tabular}{l} 
Internal partitions \\
\hline $\begin{array}{l}\text { Dwelling internal } \\
\text { partitions }\end{array}$
\end{tabular} & 2.29 & 33.13 & 2.29 & 33.13 & 2.29 & 33.13 \\
\hline
\end{tabular}

\subsection{Energy simulation. Operational patterns}

The energy evaluation of dwellings was conducted with software Energy Plus 8.1. [68]. Weather data for the city of Ávila was taken from the Spanish Weather for Energy Calculations - SWEC [69] and weather data for Madrid and Seville was obtained from the International Weather for Energy Calculations - IWEC [70].

The research aimed to evaluate the energy performance of each dwelling so as to understand each household condition. For that purpose, the most representative dwellings were selected from each block according to their relative position within the building. In this way, nine flats were evaluated from each block as displayed in Figure 6.
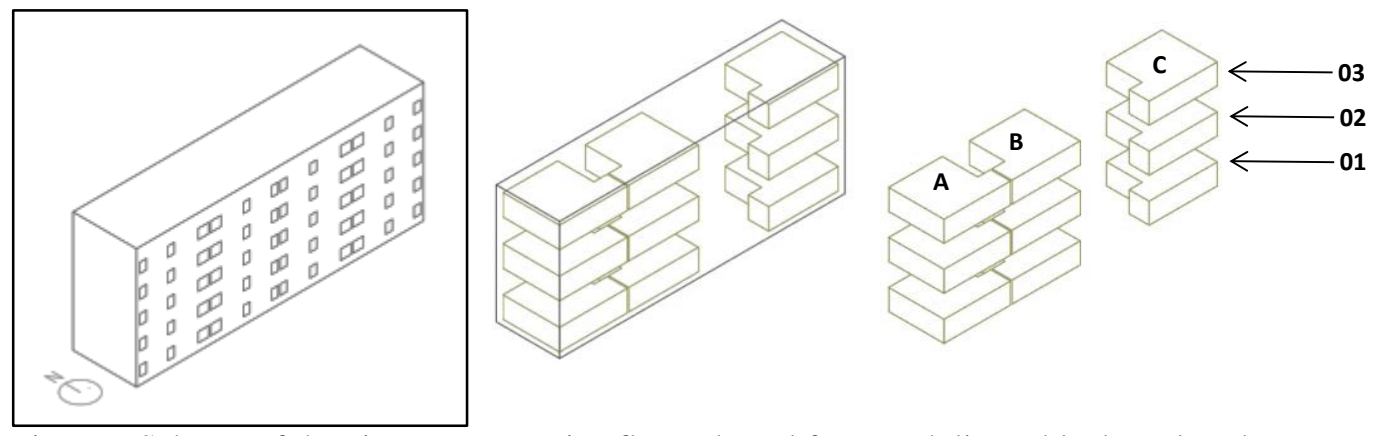

Figure 6 Scheme of the nine representative flats selected from each linear block analysed. 
Table 4. Occupational patterns considered for dwellings [63]

\begin{tabular}{|c|c|c|c|c|c|c|c|}
\hline \multirow{3}{*}{ Sensible occupancy $\left(\mathrm{W} / \mathrm{m}^{2}\right)$} & \multicolumn{7}{|c|}{ Hours } \\
\hline & \multirow{2}{*}{$1-7$} & \multirow[t]{2}{*}{8} & \multirow[t]{2}{*}{$9-15$} & \multirow[t]{2}{*}{$16-18$} & \multirow[t]{2}{*}{19} & \multirow[t]{2}{*}{$20-23$} & \multirow[t]{2}{*}{24} \\
\hline & & & & & & & \\
\hline Workday & 2.15 & 0.54 & .54 & 1.08 & 1.08 & 1.08 & 2.15 \\
\hline Weekend & 2.15 & 2.15 & 2.15 & 2.15 & 2.15 & 2.15 & 2.15 \\
\hline \multicolumn{8}{|l|}{ Latent occupancy $\left(\mathrm{W} / \mathrm{m}^{2}\right)$} \\
\hline Workday & 1.36 & 0.34 & 0.34 & 0.68 & 0.68 & 0.68 & 1.36 \\
\hline Weekend & 1.36 & 1.36 & 1.36 & 1.36 & 1.36 & 1.36 & 1.36 \\
\hline \multicolumn{8}{|l|}{ Lighting $\left(\mathrm{W} / \mathrm{m}^{2}\right)$} \\
\hline All days & 0.44 & 1.32 & 1.32 & 1.32 & 2.20 & 4.40 & 2.20 \\
\hline \multicolumn{8}{|l|}{ Equipment $\left(\mathrm{W} / \mathrm{m}^{2}\right)$} \\
\hline All days & 0.44 & 1.32 & 1.32 & 1.32 & 2.20 & 4.40 & 2.20 \\
\hline Summertime ventilation (ach/hour) & 4.00 & 4.00 & $*$ & $*$ & $*$ & $*$ & $*$ \\
\hline All year ventilation & $*$ & $*$ & $*$ & $*$ & $*$ & $*$ & $*$ \\
\hline
\end{tabular}

Occupational patterns were set according to those used in the Spanish Technical Code criteria to evaluate Spanish building energy ratings [63]. Thus, internal gains were broken down into occupancy, equipment and lighting. Minimal ventilation rates were set following indoor thermal quality Spanish Technical Code requirements (Ministerio de Fomento, 2013) and infiltration rates were set based on the Annex II of Manual of Technical Basis for existing building energy rating [71]. Finally, night summer ventilation was considered as established in Spanish Energy Rating software. These values are shown in Table 4.

\subsection{Adaptive comfort standard 55-2013. Adjustments for its use in dwellings}

The evaluation of indoor thermal comfort in selected dwellings was conducted through the adaptive model from ASHRAE updated in its last version 55-2013 [72]. This standard was considered to be the most suitable for the purpose of the study given that:

a) It assesses the occupants' ability to adapt to climate, so it enables considering Spanish climatic diversity.

b) Fuel poor households can hardly use their heating and cooling systems, which makes indoor thermal conditions mainly rely on their dwellings' passive thermal behaviour.

c) Finally, domestic space can be considered the one where occupants enjoy the widest range of adaptation abilities, which is in accordance with the adaptive standard. 
Considering ASHRAE 55-2013 for the evaluation of indoor thermal comfort in dwellings, some adjustments were required. The general formula was used to estimate the neutral operative temperature $\left(T_{o t}\right)$ based on monthly mean external temperature $\left(T_{o}\right)$ as allowed in the Standard:

$T_{o t}=0.31 T_{o}+17.8^{\circ} \mathrm{C}$

Comfort thresholds were set for the $80 \%$ acceptability limits considering these boundaries suitable for the majority of households. The $90 \%$ would be advisable for households with higher requirements of thermal comfort, such as those occupied by elderly persons or by people suffering from chronic diseases.

Despite the fact that the ASHRAE Standard is suitable for a metabolic rate between 1 and 1.3 met, which matches the metabolic rates range assumed for dwellings, during sleeping time this metabolic rate decreases to around 0.8 met [47]. Considering that a modification of 0.1 met results into a variation of $0.1^{\circ} \mathrm{C}$ in thermal comfort temperature, this decrease of 0.2 met resulted into an increase of comfort range of $+0.2^{\circ} \mathrm{C}$. Besides metabolic rates, adjustments for clothing levels were considered as well. The ASHRAE Standard assumes clothing levels between 0.5 and 1 clo, but it is known that in dwellings clothing variability is higher, in line with results of project RP-884 [73]. Hence, for the heating season an increase in clothing levels up to 1.5 clo was assumed for night time hours, which resulted in a decrease in comfort thresholds of $3^{\circ} \mathrm{C}$. On the other hand, for the summer season, a decrease in clothing levels during sleeping hours of up to 0.3 clo was assumed, which resulted into an increase in comfort thresholds of $1.2^{\circ} \mathrm{C}$. As a result, thermal comfort boundaries were extended as summarized in Table 5 .

Table 5. Comfort temperature boundaries adjustments for night time hours

\begin{tabular}{|c|c|c|c|c|c|c|c|}
\hline & \multicolumn{3}{|c|}{ Metabolic rate } & \multicolumn{3}{|c|}{ Clothing level } & \multirow{2}{*}{$\begin{array}{c}\text { Final } \\
\text { temperature } \\
\text { adjustment* }\end{array}$} \\
\hline & Daytime & $\begin{array}{c}\text { Night } \\
\text { time }\end{array}$ & $\begin{array}{c}\text { Temperature } \\
\text { adjustment }\end{array}$ & Daytime & Night time & $\begin{array}{c}\text { Temperature } \\
\text { adjustment }\end{array}$ & \\
\hline $\begin{array}{l}\text { Underheated } \\
\text { season }\end{array}$ & $\begin{array}{c}1-1.3 \\
\text { met }\end{array}$ & $0.8 \mathrm{met}$ & $+0.2^{\circ} \mathrm{C}$ & $0.5-1$ clo & 1.5 clo & $-3^{\circ} \mathrm{C}$ & $-2.8^{\circ} C^{*}$ \\
\hline $\begin{array}{l}\text { Overheated } \\
\text { season }\end{array}$ & $\begin{array}{c}1-1.3 \\
\text { met }\end{array}$ & $0.8 \mathrm{met}$ & $+0.2^{\circ} \mathrm{C}$ & $0.5-1$ clo & 0.3 clo & $+1.2^{\circ} \mathrm{C}$ & $+1.4^{\circ} \mathrm{C}$ \\
\hline
\end{tabular}

*Comfort temperatures adjustments for the underheated season were limited to $16^{\circ} \mathrm{C}$ in line with studies that point this temperature as the threshold for respiratory diseases [74].

Once temperature comfort boundaries were calculated for each climate, energy simulation of selected dwellings was conducted in order to set the amount of energy required in each case in 
order to achieve indoor thermal comfort in dwellings. This amount of energy that provides adaptive thermal comfort levels was defined as adaptive energy demand.

\subsection{Comparison with conventional energy demand calculations}

The adaptive demand was compared to conventional calculations of energy demand in order to understand the main differences of the two methods. For the conventional calculation of energy demand, thermostat temperature setpoints, shown in Table 6, were set based on the Spanish Technical Code criteria for evaluating the energy performance of Spanish buildings [63]. According to these criteria, two temperature setpoints are considered for the heating season; $17^{\circ} \mathrm{C}$ for night time hours and $20^{\circ} \mathrm{C}$ for daytime ones. The cold season is defined as the period from October to May. For the cooling season, which is defined as the period from June to September for all climates, two setpoints are set; $27^{\circ} \mathrm{C}$ for sleeping hours and $25^{\circ} \mathrm{C}$ for daytime ones. It must be noted that from 8:00 to 15:00 dwellings are considered to be in free running mode irrespective of indoor overheating occurring or not

Table 6. Thermostat temperature setpoints in conventional energy demand calculations for dwellings [63]

\begin{tabular}{|c|c|c|c|c|c|c|}
\hline & & \multicolumn{5}{|c|}{ Hours } \\
\hline & & $1-7$ & 8 & $9-15$ & $16-23$ & 24 \\
\hline \multirow{3}{*}{ Heating Setpoint temperature $\left({ }^{\circ} \mathrm{C}\right)$} & January - May & 17 & 20 & 20 & 20 & 17 \\
\hline & June - September & - & - & - & - & - \\
\hline & October - December & 17 & 20 & 20 & 20 & 17 \\
\hline \multirow{3}{*}{ Cooling Setpoint temperature $\left({ }^{\circ} \mathrm{C}\right)$} & January - May & - & - & - & - & - \\
\hline & June - September & 27 & - & - & 25 & 27 \\
\hline & October - December & - & - & - & - & - \\
\hline
\end{tabular}

\section{Results}

\subsection{Adaptive temperature thresholds for selected climates}

Comfort temperature thresholds were calculated for each climate region based on mean monthly outdoor temperatures, according to the ASHRAE Standard. Night time adjustments were made as explained in section 4.4. The new monthly comfort temperature thresholds in relation to the monthly mean temperatures are shown in Figure 7 for the climate of Ávila, in Figure 8 for the climate of Madrid and in Figure 9 for the climate of Seville. Comfort boundaries vary among climates in contrast to fixed thresholds usually applied in heating and cooling calculations. For the 
coldest months, the three climates present the same boundaries as the Standard limits its application to outdoor mean temperature values below $10^{\circ} \mathrm{C}$. By contrast, these climates present important differences during the hottest months. Extreme temperatures are registered in Seville where the upper comfort temperature threshold reaches $29.8^{\circ} \mathrm{C}$ during daytime hours. In Madrid, this value goes up to $29.2^{\circ} \mathrm{C}$, while this value is $27.5^{\circ} \mathrm{C}$ for Ávila.

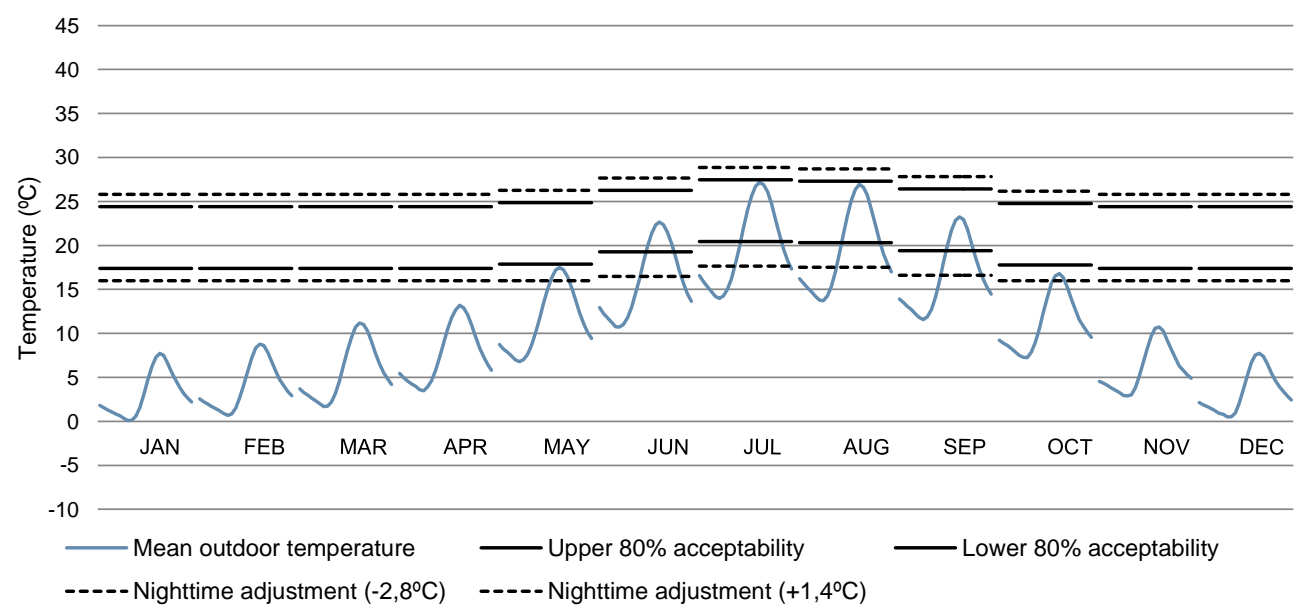

Figure 7 Monthly thermal comfort boundaries for the $80 \%$ of acceptability according to Ashrae 552013 plus dwelling night time adjustments for the climate of Avila.

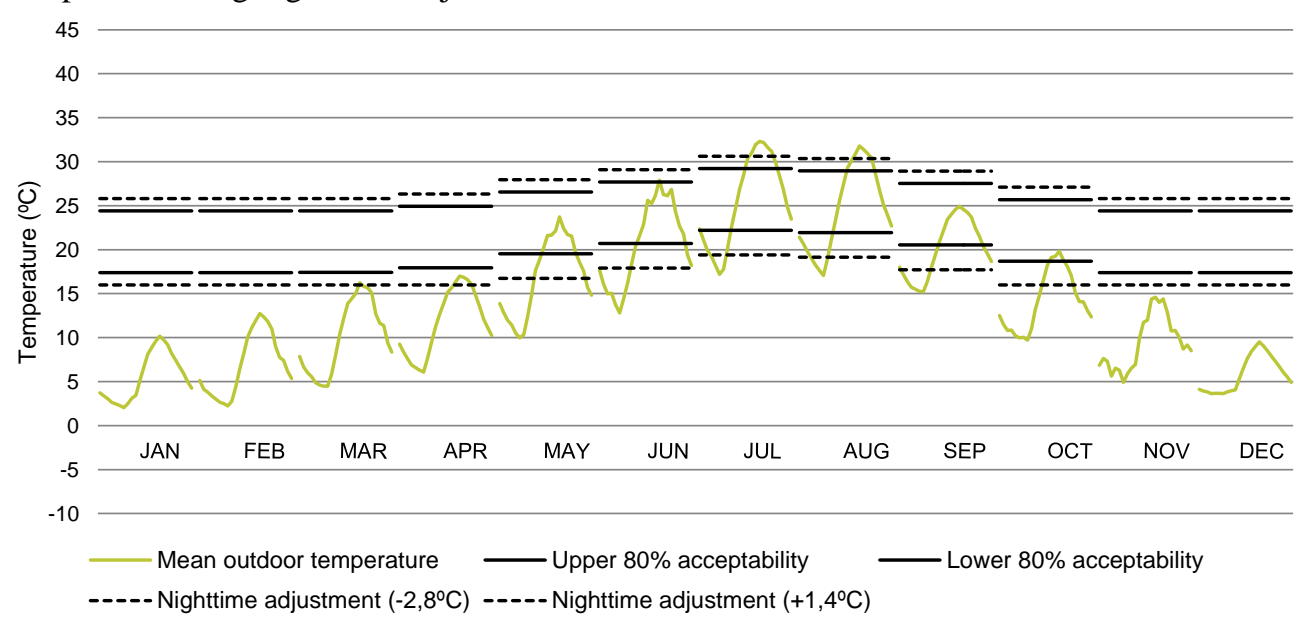

Figure 8 Monthly thermal comfort boundaries for the $80 \%$ of acceptability according to Ashrae 552013 plus dwelling night time adjustments for the climate of Madrid. 


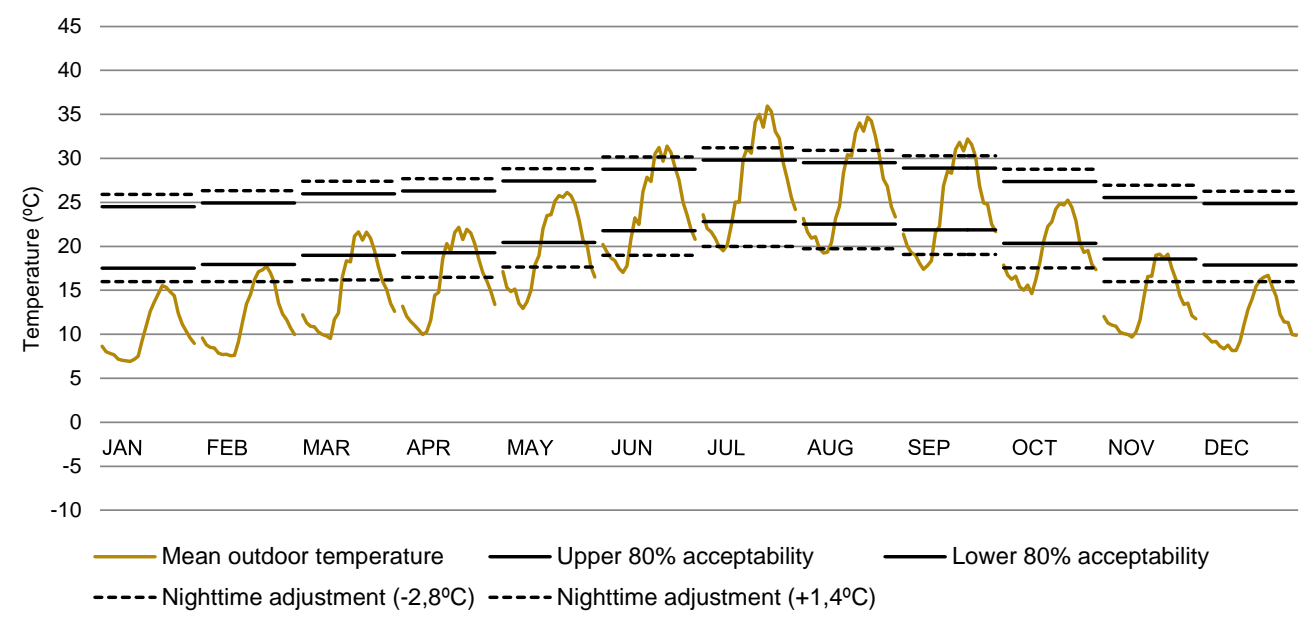

Figure 9 Monthly thermal comfort boundaries for the $80 \%$ of acceptability according to Ashrae 552013 plus dwelling night time adjustments for the climate of Seville.

\subsection{Thermal comfort in dwellings: the evaluation of the adaptive demand}

Results of the adaptive demand of the blocks under examination can be seen in Figure 10. Data was broken down by heating adaptive demand for the underheated period and cooling adaptive demand for the overheated one, as well as by the nine representative dwellings selected within each linear block. Results show that these dwellings do not achieve minimal thermal comfort levels for their occupants, otherwise adaptive demand should tend to zero.

Differences among climates can be observed. Heating adaptive demand in Avila's dwellings ranges from around 80 to $150 \mathrm{kWh} / \mathrm{m}^{2} \mathrm{~h}$ while those in Seville present values between 15 and $45 \mathrm{kWh} / \mathrm{m}^{2}$, which represents less than half the amount of energy required in Avila. Dwellings' adaptive energy demand from Madrid ranges between 60 and $110 \mathrm{kWh} / \mathrm{m}^{2}$. Overheating problems also vary from one climate to another. Dwellings from Ávila do not present any cooling demand while those from Seville adaptive demand results go up to $40 \mathrm{kWh} / \mathrm{m}^{2}$. Dwellings from Madrid also present overheating problems but with lower values, around $30 \mathrm{kWh} / \mathrm{m}^{2}$ per year.

Differences among dwellings can be assessed as well, according to their relative position within the block. Floor level influence is clearly reflected on dwellings from Ávila and Madrid where top and ground floors present the highest heating demand, mainly caused by limited thermal enclosure. Regarding cooling demand, top floors present greater overheating problems due to solar radiation incidence over roofs while ground floors, as a result of the ground floor radiant cooling effect enjoy better thermal conditions during summer time. Dwelling position within each floor can also 
be noted in energy demand. Those located in the middle of the block have lower heating requirements than those located in the edges, as they have less exposed surfaces.

\subsection{Adaptive demand vs. conventional energy demand}

Results of heating and cooling demand according to the conventional method are shown in Figure 10 along with the adaptive demand method results. Similarly to the adaptive demand values, variations in conventional energy demand values can be observed among the modeled dwellings. As previously described, these variations are related to climate, dwelling floor location (top, middle or ground floor) and floor position (inner or outer position).

In all cases, adaptive demand is lower than conventional demand. The largest deviations in heating demand can be seen in Ávila's middle and ground floor dwellings where adaptive demand is almost $30 \mathrm{kWh} / \mathrm{m}^{2}$ year lower and requires around $20 \%$ less energy than the conventional one. Regarding cooling energy needs, adaptive demand for Seville's dwellings can be up to 20 $\mathrm{kWh} / \mathrm{m}^{2}$ year lower than conventional demand which, in some cases, can represent an $80 \%$ energy demand reduction. 

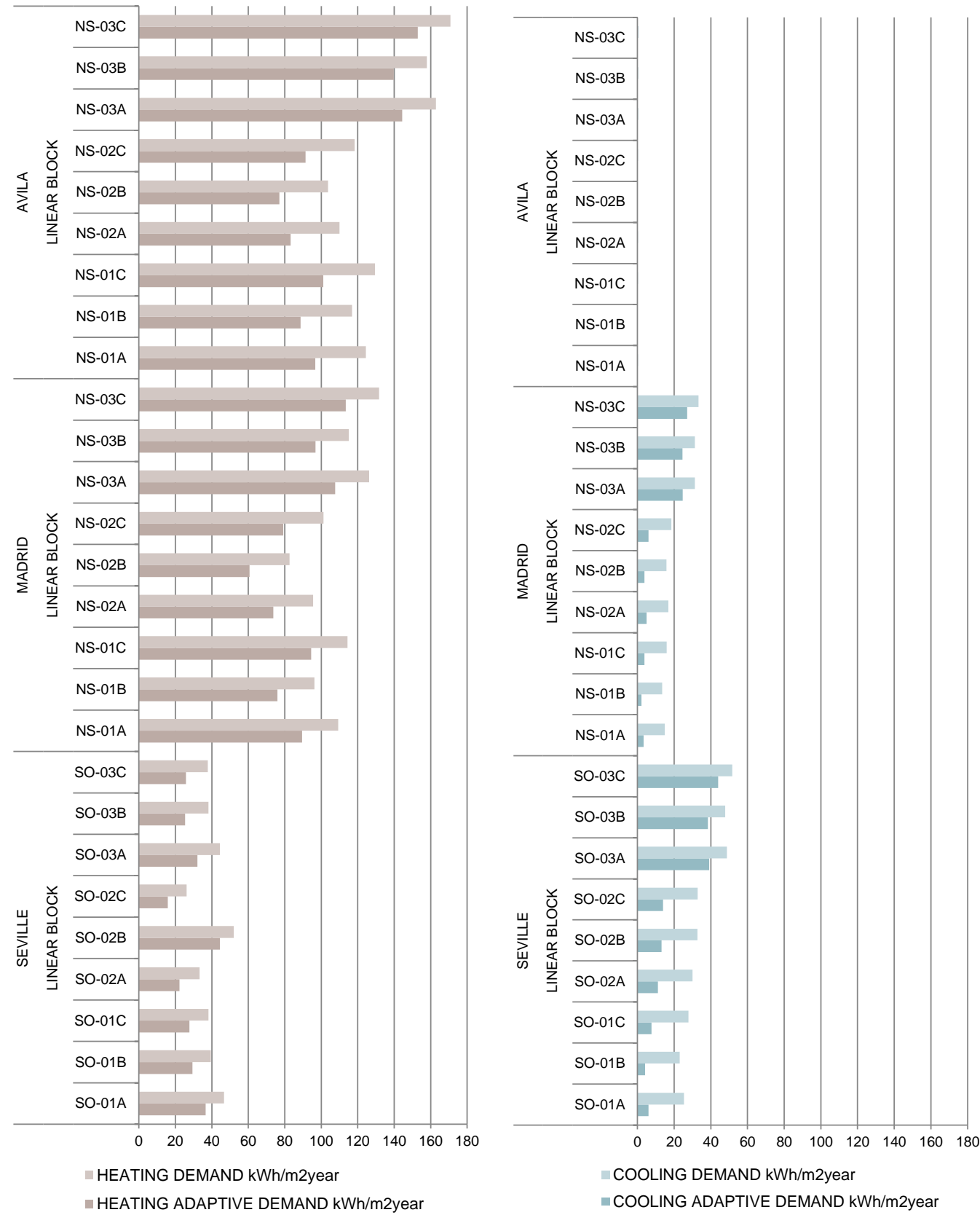

Figure 10 Comparison between conventional energy demand and adaptive demand results of studied dwellings $\left(\mathrm{kWh} / \mathrm{m}^{2}\right)$ for heating (left) and cooling (right).

\section{Discussion}

This study aimed to identify minimal thermal habitability conditions for low income dwelling types in Spain for a wide range of climatic contexts. In order to achieve that, selected climates that represent winter and summer extreme conditions in Spain were studied, from the coldest winter conditions in Ávila to the hottest summers in Seville. The use of the adaptive thermal comfort criteria enabled the analysis of population's ability to adapt to the climate they live, which showed 
important differences in comfort threshold requirements. While the cold winter conditions in Ávila result in almost constant adaptive thermal comfort boundaries from November to April ranging from $17.4^{\circ} \mathrm{C}$ to $24.4^{\circ} \mathrm{C}$ during daytime, Seville's summer time reaches maximum adaptive comfort thresholds in July with a temperature range between $22.8^{\circ} \mathrm{C}$ and $29.8^{\circ} \mathrm{C}$. These numbers represent a non-negligible comfort window between extreme temperatures of $12.4^{\circ} \mathrm{C}$.

To cope with excess cold or heat indoors, fuel poor households commonly rely on passive thermal behaviour instead of costly active heating and cooling systems. In addition, domestic spaces offer a wide range of occupant thermal adaptability options. Taking these into consideration, the ASHRAE adaptive standard was deemed more appropriate for the estimation of thermal comfort in dwellings. As previously pointed by other authors [62], metabolic and clothing values during daytime are similar to those considered in the Standard. In this study, changes in clothing and metabolic rates during night time were specified by using previously established values [47].

Thermal comfort in dwellings is usually evaluated by estimating the number or the percentage of hours beyond defined thresholds, or the length of the period during which extreme temperatures occur. By contrast, this research is focused on evaluating the energy required to achieve these minimal thermal habitability conditions based on the adaptive comfort criteria. This energy demand was defined as adaptive demand.

The evaluation of the adaptive demand of selected dwellings has shown important differences among their energy requirements related, first, to the climate they are located and second, to their relative position within the block. Due to climatic differences, heating adaptive demand can be double that of Seville in Ávila, while cooling adaptive demand can be zero in Ávila and up to 40 $\mathrm{kWh} / \mathrm{m}^{2}$ in Seville. The relative position of dwellings within the block has also resulted in large differences in the adaptive demand results. Top and ground floors present highest heating energy requirements while top floors are those where largest cooling energy needs were obtained.

The comparison between adaptive demand and conventional energy demand results showed energy requirements to reach adaptive thermal thresholds to be lower than conventional thresholds for all analysed cases. This is unsurprising as adaptive comfort boundaries are less restrictive than conventional fixed thresholds. Shifting from the conventional to the adaptive energy demand, a reduction in heating requirements of up to $20 \%$ and a decrease in cooling needs of up to $80 \%$ was 
obtained. It should be noted that adaptive demand is calculated using operative temperatures, which enables a more accurate evaluation of occupants' thermal experience in contrast to conventional calculations that work with air temperature. Furthermore, adaptive standard calculations do not work with fixed seasons but with real temperature data, while conventional energy demand calculations establish a heating period from October to May and a cooling season from June to September which is not always appropriate for some Spanish climate regions.

\section{Conclusions}

This paper aimed to explore the minimal thermal habitability conditions to be achieved in low income dwellings in Spain in order to lay the foundations for a new definition and methodology of fuel poverty in this country. Results of this research showed that the use of the adaptive comfort standard criteria is a useful method to help establish these minimal thermal conditions. The study enabled the review of the suitability of other fuel poverty definitions temperature thresholds for the Spanish context as well as incorporating temperature baselines for the hot season. Importantly, this research presents a method to include energy cooling needs in the definition of fuel poverty for the Spanish population, in contrast to traditional definitions focused exclusively on heating needs. This study can set the basis for fuel poverty definitions for all Mediterranean and Southern European countries developing their own methodologies.

Furthermore, the definition of the adaptive demand as the energy required to achieve minimal thermal habitability can have important energy policy implications given the deviation from conventional energy demand calculations. First, the estimation of adaptive demand for each household instead of the whole block demonstrated that household heating and cooling needs can vary appreciably within the same block. Differences in household energy demand values between conventional and adaptive energy demand calculations can lead to a critical review of the way building energy rating is being determined. Last, such discrepancies can have an important impact on current estimations of household energy consumption and, thus, in the way energy savings and payback time due to energy retrofitting is being estimated. 


\section{Acknowledgments}

The authors would like to thank Prof Mike Davies from University College London (UCL) and Prof Paul Wilkinson from the London School of Hygiene and Tropical Medicine (LSHTM) for their initial comments on the research, as well as contributions of members of the Complex Built Environment Systems group (CBES) based at the Institute for Environmental Design and Engineering (IEDE), The Bartlett, UCL.

\section{Funding}

This research was partly funded by Technical University of Madrid Programme to perform short stays in foreign institutions.

\section{References}

[1] European Parliament, Directive 2009/72/EC of the European Parliament and the Council of 13 July 2009 concerning common rules for the internal market in electricity and repealing Directive 2003/54/EC (Text with EEA relevance), (2009) 55-93.

[2] European Parliament, Directive 2009/73/EC of the European Parliament and the Council of 13 July 2009 concerning common rules for the internal market in natural gas and repealing Directive 2003/55/EC (Text with EEA relevance), (2009) 94-136. doi:10.1126/science.202.4366.409.

[3] European Parliament, Directive 2010/31/EU of the European Parliament and of the Council of 19 May 2010 on the energy performance of buildings (recast), (2010) 13-35.

[4] European Parliament, Directive 2012/27/EU of the European Parliament and of the Council of 25 October 2012 on energy efficiency, amending Directives 2009/125/EC and 2010/30/EU and repealing Directives 2004/8/EC and 2006/32/EC (Text with EEA relevance), (2012) 1-56.

[5] European Commission, Europe 2020. A strategy for smart, sustainable and inclusive growth. Communication from the Commission, Brussels, 2010. http://eurlex.europa.eu/LexUriServ/LexUriServ.do?uri=COM:2010:2020:FIN:EN:PDF～(accessed January 24, 2014). 
[6] UK Parliament, Warm Homes and Energy Conservation Act, 2000.

[7] S. Scott, S. Lyons, C. Keane, D. Mccarthy, R.S.J. Tol, Working Paper No. 262 Fuel Poverty in Ireland: Extent, Affected Groups and Policy Issues, (2008).

[8] Department of Communications Energy and Natural Resources. Irish Government, Warmer Homes. A Strategy for Affordable Energy in Ireland, (2011) 82.

[9] Assemblée Nationale Française, Loi Grenelle II. Engagement national pour l'environnement, 576 (2010) 308.

[10] I. Imbert, P. Nogues, M. Sevenet, Same but different: On the applicability of fuel poverty indicators across countries - Insights from France, Energy Res. Soc. Sci. 15 (2016) 75-85. doi:10.1016/j.erss.2016.03.002.

[11] I. Househam, V. Musatescu, Fuel poverty. Draft assessment report., 2012. doi:10.1016/0959-3780(93)90034-I.

[12] S. Buzar, The "hidden" geographies of energy poverty in post-socialism: Between institutions and households, Geoforum. $38 \quad$ (2007) 224-240. doi:10.1016/j.geoforum.2006.02.007.

[13] M. Frondel, S. Sommer, C. Vance, The burden of Germany's energy transition: An empirical analysis of distributional effects, Econ. Anal. Policy. 45 (2015) 89-99. doi:10.1016/j.eap.2015.01.004.

[14] A. Atsalis, S. Mirasgedis, C. Tourkolias, D. Diakoulaki, Fuel poverty in Greece: Quantitative analysis and implications for policy, Energy Build. 131 (2016) 87-98. doi:10.1016/j.enbuild.2016.09.025.

[15] B. Legendre, O. Ricci, Measuring fuel poverty in France: Which households are the most fuel vulnerable?, Energy Econ. 49 (2014) 620-628. doi:10.1016/j.eneco.2015.01.022.

[16] K. Fabbri, Building and fuel poverty, an index to measure fuel poverty: An Italian case study, Energy. 89 (2015) 244-258. doi:10.1016/j.energy.2015.07.073.

[17] R. Miniaci, C. Scarpa, P. Valbonesi, Energy affordability and the benefits system in Italy, Energy Policy. 75 (2014) 289-300. doi:10.1016/j.enpol.2014.09.008. 
[18] S. Bouzarovski, S. Petrova, A global perspective on domestic energy deprivation: Overcoming the energy poverty-fuel poverty binary, Energy Res. Soc. Sci. 10 (2015) 3140. doi:10.1016/j.erss.2015.06.007.

[19] R. Barbosa, R. Vicente, R. Santos, Climate change and thermal comfort in Southern Europe housing: A case study from Lisbon, Build. Environ. 92 (2015) 440-451. doi:10.1016/j.buildenv.2015.05.019.

[20] A. Sakka, M. Santamouris, I. Livada, F. Nicol, M. Wilson, On the thermal performance of low income housing during heat waves, Energy Build. 49 (2012) 69-77. doi:10.1016/j.enbuild.2012.01.023.

[21] a. Mavrogianni, J. Taylor, M. Davies, C. Thoua, J. Kolm-Murray, Urban social housing resilience to excess summer heat, Build. Res. Inf. 43 (2015) 316-333. doi:10.1080/09613218.2015.991515.

[22] J. Taylor, M. Davies, A. Mavrogianni, C. Shrubsole, I. Hamilton, P. Das, B. Jones, E. Oikonomou, P. Biddulph, Mapping indoor overheating and air pollution risk modification across Great Britain: A modelling study, Build. Environ. 99 (2016) 1-12. doi:10.1016/j.buildenv.2016.01.010.

[23] P. Grösche, Housing, energy cost, and the poor: Counteracting effects in Germany's housing allowance program, Energy Policy. $38 \quad$ (2010) 93-98. doi:10.1016/j.enpol.2009.08.056.

[24] M. Santamouris, K. Kapsis, D. Korres, I. Livada, C. Pavlou, M.N. Assimakopoulos, On the relation between the energy and social characteristics of the residential sector, Energy Build. 39 (2007) 893-905. doi:10.1016/j.enbuild.2006.11.001.

[25] M. Santamouris, J. Paravantis, D. Founda, D. Kolokotsa, P. Michalakakou, A. Papadopoulos, N. Kontoulis, A. Tzavali, E.K. Stigka, Z. Ioannidis, A. Mehilli, A. Matthiessen, E. Servou, Financial crisis and energy consumption: A household survey in Greece, Energy Build. 65 (2013) 477-487. doi:10.1016/j.enbuild.2013.06.024.

[26] G. Pignatta, C. Chatzinikola, G. Artopoulos, C.N. Papanicolas, D.K. Serghides, M. Santamouris, Analysis of the indoor thermal quality in low income Cypriot households 
during winter, Energy Build. (2016). doi:10.1016/j.enbuild.2016.11.006.

[27] C. Sánchez-Guevara, A. Sanz Fernández, A. Hernández Aja, Income, energy expenditure and housing in Madrid: retrofitting policy implications, Build. Res. Inf. 3218 (2014) 1-13. doi:10.1080/09613218.2014.984573.

[28] C. Sánchez-Guevara Sánchez, A. Sanz Fernández, A. Hernández Aja, F.J. Neila González, Fuel poverty analysis in three Spanish Autonomous Regions. Some retrofitting policy considerations, in: III Int. Congr. Constr. Build. Res. COINVEDI, Madrid, 2015: pp. 204205.

[29] D. Kolokotsa, M. Santamouris, Review of the indoor environmental quality and energy consumption studies for low income households in Europe, Sci. Total Environ. 536 (2015) 316-330. doi:10.1016/j.scitotenv.2015.07.073.

[30] P. Wilkinson, K.R. Smith, S. Beevers, C. Tonne, T. Oreszczyn, Energy, energy efficiency, and the built environment, Lancet. 370 (2007) 1175-1187. doi:10.1016/S01406736(07)61255-0.

[31] J.D. Healy, Excess winter mortality in Europe: a cross country analysis identifying key risk factors., J. Epidemiol. Community Health. $57 \quad$ (2003) 784-9. http://www.pubmedcentral.nih.gov/articlerender.fcgi?artid=1732295\&tool=pmcentrez\&re ndertype $=$ abstract

[32] World Health Organization, The Effects of the Indoor Housing Climate on the Health of the Elderly: Report of a WHO working Group, Copenague, 1984.

[33] D. Ormandy, V. Ezratty, Health and thermal comfort: From WHO guidance to housing strategies, Energy Policy. 49 (2012) 116-121. doi:10.1016/j.enpol.2011.09.003.

[34] World Health Organization, Health impact of low indoor temperatures, Copehnaguen, 1987.

[35] K.B.G. Dear, A.J. McMichael, The health impacts of cold homes and fuel poverty., BMJ. 342 (2011) d2807. doi:10.1136/bmj.d2807.

[36] J.-M. Robine, S.L.K. Cheung, S. Le Roy, H. Van Oyen, C. Griffiths, J.-P. Michel, F.R. Herrmann, Death toll exceeded 70,000 in Europe during the summer of 2003., C. R. Biol. 
331 (2008) 171-8. doi:10.1016/j.crvi.2007.12.001.

[37] R. Basu, Relation between Elevated Ambient Temperature and Mortality: A Review of the Epidemiologic Evidence, Epidemiol. Rev. 24 (2002) 190-202. doi:10.1093/epirev/mxf007.

[38] J. Díaz, C. Linares, A. Tobías, Impact of extreme temperatures on daily mortality in Madrid (Spain) among the 45-64 age-group., Int. J. Biometeorol. 50 (2006) 342-8. doi:10.1007/s00484-006-0033-z.

[39] C.R. Browning, S.L. Feinberg, D. Wallace, A. Kathleen, Neighborhood Social Processes , Physical Conditions, and Disaster-Related Mortality: The Case of the 1995 Chicago Heat Wave, (2012).

[40] IPCC, WORKING GROUP I CONTRIBUTION TO THE IPCC FIFTH ASSESSMENT REPORT CLIMATE CHANGE 2013 : THE PHYSICAL SCIENCE BASIS Final Draft Underlying Scientific-Technical Assessment A report accepted by Working Group I of the IPCC but not approved in detail ., (2013).

[41] C. Linares, sobre la mortalidad diaria según diferentes grupos de edad, 22 (2008) 115-119.

[42] J. Díaz Jiménez, Cambio global 2020/50 Cambio climático y salud, Madrid, 2012.

[43] M.S. Goromosov, GOROMOSOV_1968_HEALTH STANDARDS DWELLINGS.pdf, 1968.

[44] WHOEurope, Large analysis and review of European housing and health status (LARES) $\begin{array}{lll}\text { Preliminary } & \text { overview, } & 2007 .\end{array}$ http://www.euro.who.int/_data/assets/pdf_file/0007/107476/lares_result.pdf?ua=1.

[45] P.. Fanger, Thermal comfort, (1970).

[46] M.A. Humphreys, Outdoor temperatures and comfort indoors, Build. Res. Pract. 6 (1976) $92-105$.

[47] International Standard Organization, ISO 7730:2005 Ergonomics of the thermal environment. Analytical determination and interpretation of thermal comfort using calculation of the PMV and PPD indices and local thermal comfort criteria, (2005) 60.

[48] J.F. Nicol, Adaptive comfort, Build. Res. Inf. 39 (2011) 105-107. 
doi:10.1080/09613218.2011.558690.

[49] M.A. Humphreys, J.F. Nicol, Understanding the adaptive approach to thermal comfort, in: ASHRAE Trans., $\quad$ ASHRAE, 1998: pp. 991-1004. http://www.scopus.com/inward/record.url?eid=2-s2.0-0031622942\&partnerID=tZOtx3y1.

[50] M. a Humphreys, J. Fergus Nicol, The validity of ISO-PMV for predicting comfort votes in every-day thermal environments, Energy Build. 34 (2002) 667-684.

[51] G.S. Brager, R.J. De Dear, Thermal adaptation in the built environment: A literature review, Energy Build. 27 (1998) 83-96. http://www.scopus.com/inward/record.url?eid=2s2.0-0031999635\&partnerID=40\&md5=5070b15ff6ac5efa2e9ee641ff86e69e.

[52] M.A. Humphreys, M. Hancock, Do people like to feel "neutral"?. Exploring the variation of the desired thermal sensation on the ASHRAE scale, Energy Build. 39 (2007) 867-874. doi:10.1016/j.enbuild.2007.02.014.

[53] M.J. Holmes, J.N. Hacker, Climate change, thermal comfort and energy: Meeting the design challenges of the 21st century, Energy Build. 39 (2007) 802-814. doi:10.1016/j.enbuild.2007.02.009.

[54] E. Glaser, The Physiological basis of habituation, Oxford University Press, London, 1966.

[55] R. Frisancho, Human adaptation and Accomodation. Enlarged and Revised Edition of Human Adaptation, The University of Michigan, 1993.

[56] Technical Committee CEN/TC 156, EN 15251:2006 Indoor environmental input parameters for design and assessment of energy performance of buildings addressing indoor air quality, thermal environment, lighting and acoustics., (2006).

[57] ASHRAE, ANSI/ASHRAE Standard 55-2010 Thermal Environmental Conditions for Human Occupancy, 8400 (2010).

[58] R. de Dear, Recent enhancements to the adaptive comfort standard in ASHRAE 55-2010, Proc. 45th Annu. Conf. Archit. Sci. Assoc. (2011).

[59] F. Nicol, M. Humphreys, Derivation of the adaptive equations for thermal comfort in freerunning buildings in European standard EN15251, Build. Environ. 45 (2010) 11-17. doi:10.1016/j.buildenv.2008.12.013. 
[60] N.A. Oseland, Predicted and reported thermal sensation in climate chambers, offices and homes, Energy Build. 23 (1995) 105-115.

[61] R. Becker, M. Paciuk, Thermal comfort in residential buildings - Failure to predict by Standard model, Build. Environ. 44 (2009) 948-960. doi:10.1016/j.buildenv.2008.06.011.

[62] L. Peeters, R. De Dear, J. Hensen, W. D'haeseleer, Thermal comfort in residential buildings: Comfort values and scales for building energy simulation, Appl. Energy. 86 (2009) 772-780. doi:10.1016/j.apenergy.2008.07.011.

[63] Ministerio de Fomento, Orden FOM/1635/2013, de 10 de septiembre, por la que se actualiza el Documento Básico DB-HE «Ahorro de Energía», del Código Técnico de la Edificación, aprobado por Real Decreto 314/2006, de 17 de marzo, (2013) 67137-67209.

[64] Ministerio de Fomento, Documento descriptivo climas de referencia. Versión 2.0, (2015) $1-7$.

[65] Meteorological State Agency, Weather normal values 1981-2010, (2011).

[66] A. Hernández Aja, M. Vázquez Espí, C. García Madruga, Á. Matesanz Parellada, E. Moreno García, J. Alguacil Gómez, J. Camacho Gutiérrez, Análisis urbanístico de Barrios Vulnerables, Madrid, 2011. http://habitat.aq.upm.es/bbvv/bbvv.html (accessed July 1, 2013).

[67] Gobierno de España, Real Decreto 2429/1979 por el que se aprueba la norma básica de la edificación NBE-CT-79 sobre condiciones térmicas en los edificios, (1979) 24524-24550. http://www.boe.es/boe/dias/1979/10/22/pdfs/A24524-24550.pdf (accessed July 2, 2013).

[68] US Department of Energy, EnergyPlus Engineering Reference. The Reference to EnergyPLus Calculations, 2014.

[69] Departament of Energy of the United States, Weather Data for Simulation, (2013). http://apps1.eere.energy.gov/buildings/energyplus/weatherdata_about.cfm?CFID=3991382 \&CFTOKEN=c349ad9d73ef7705-6B68C83B-02D5-F0A5-BC22206336E8778D (accessed October 1, 2015).

[70] ASHRAE, International Weather for Energy Calculations (IWEC Weather Files) Users Manual and CD-ROM, Atlanta, 2001. 
[71] Instituto para la Diversificación y Ahorro de la Energía, Manual de fundamentos técnicos de calificación energética de edificiosexistentes CE3, Madrid, 2012.

[72] ASHRAE, ANSI/ASHRAE Standard 55-2013. Thermal Environmental Conditions for Human Occupancy, (2013) 58.

[73] R.J. de Dear, G.S. Brager, ASHRAE RP-884 final report: Developing an Adaptive Model of Thermal Comfort and Preference, 1998.

[74] K.J. Collins, Low indoor temperatures and morbidity in the elderly, Age Ageing. 15 (1986) 212-220. doi:10.1093/ageing/15.4.212. 